\title{
Pengenalan Teknik Dasar Overhaul Mesin Piston Pesawat Udara Tipe Opposed untuk Guru SMK Penerbangan
}

\author{
Wira Ghautama ${ }^{1}$, Djoko Herwanto ${ }^{2}$, Lilies Esthi Riyanti ${ }^{3}$, Mursyidin ${ }^{4}$, Andri Kurniawan ${ }^{5}$ \\ Politeknik Penerbangan Indonesia Curug
}

email: wira.ghautama@ppicurug.ac.id

\begin{abstract}
Abstrak
Kegiatan pelatihan ini dilatarbelakangi oleh masih rendahnya jumlah dan kompetensi guru bidang produktif sekolah menengah kejuruan penerbangan. Data pemerintah tahun 2019 memperlihatkan mayoritas postur tenaga pengajarnya masih didominasi oleh kategori bidang normative adaptif atau guru umum, sedangkan guru produktif yang mengajar materi pelajaran sesuai bidang keahliannya masih rendah, pada prosentase di bawah $35 \%$. Tujuan pelatihan menggenalkan teknik dasar overhaul mesin piston pesawat udara tipe opposed untuk guru-guru SMK Penerbangan. Sebagai bentuk tanggung jawab pengabdian kepada masyarakat, dosen - dosen memberikan pelatihan dalam bentuk pengenalan dasar overhaul mesin piston sehingga guru - guru produktif dapat memiliki pemahaman dan terampil dalam perawatan mesin piston dengan menggunakan perkakas yang standar. Dengan lokasi kegiatan di SMKN 12 Bandung yang memiliki jurusan Airframe and Powerplant. Metode kegiatan ini dimulai dengan pembekalan konsep overhaul, pengantar penggunaan perkakas standar, regulasi dan cara pembacaan manual dan manufacture technical publication lainnya. Setelah peserta memiliki dasar penguasaan konsep tersebut, kegiatan dilanjutkan dengan pengenalan suku cadang mesin piston dan pelatihan top end overhaul sesuai dengan tujuan pelatihan. Hasil dari pelatihan ini, guru-guru telah memiliki pemahaman dan keterapilan overhaul mesin piston pesawat yang sesuai dengan manufacture manual sehingga dapat meningkatkan kualitas ajar bidang produktif.
\end{abstract}

Kata Kunci: Piston Engine, Airframe and Powerplant, Manufacture Manual

\begin{abstract}
This training activity was motivated by the low number and competence of teachers in the productive field of aviation vocational high schools. Government data for 2019 shows that the majority of teaching staff postures are still dominated by the category of adaptive normative fields or general teachers, while productive teachers who teach subject matter according to their fields of expertise are still low, at a percentage below 35\%. The aim of the training is to introduce the basic technique of overhauling opposed type aircraft piston engines for teachers of Aviation Vocational Schools. As a form of community service responsibility, lecturers provide training in the form of a basic introduction to piston engine overhaul so that productive teachers can have an understanding and skill in piston engine maintenance using standard tools. With the location of the activity at SMKN 12 Bandung which has a major in Airframe and Powerplant. The method of this activity begins with briefing on the concept of overhaul, introduction to the use of standard tools, regulations and how to read manuals and other manufacturing technical publications. After the participants have basic mastery of the concept, the activity continues with the introduction of piston engine parts and top end overhaul training in accordance with the training objectives. As a result of this training, teachers already have the understanding and overhaul skills of aircraft piston engines that are in accordance with the manufacture manual so that they can improve the teaching quality of productive fields.
\end{abstract}

Keywords: Piston Engine, Airframe and Powerplant, Manufacture Manual 


\section{Pendahuluan}

\section{Analisis Situasi}

a. Profil Mitra Lokasi Kegiatan

Sekolah Menengan Kejuruan Negeri 12 Kota Bandung adalah sekolah tingkat menengah yang berlokasi di Jalan Pajajaran no. 92 ini menempati lahan seluas $23.956 \mathrm{~m}^{2}$. SMKN 12 Kota Bandung awalnya bernama STM Penerbangan Negeri Bandung yang mulai beroperasi pada bulan Juli 1985 .

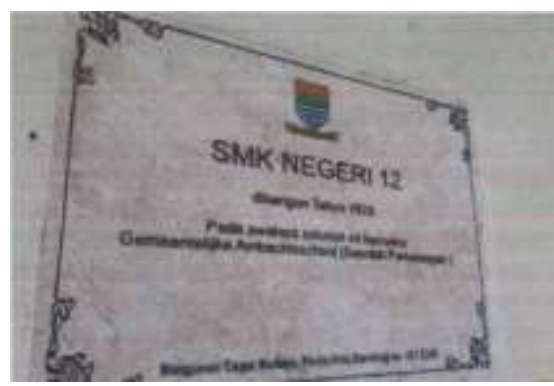

Prasasti Sekolah

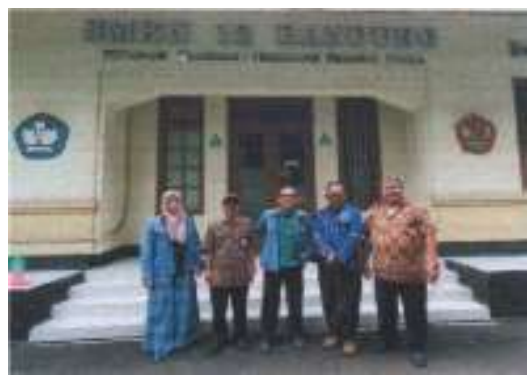

Gedung Sekolah

Gambar 1 Gedung SMKN 12 Bandung

b. Permasalahan Mitra Kegiatan

Jurusan Airframe dan Powerplant adalah jurusan yang baru dibuka di SMKN 12 pada tahun 2012 untuk mengantisipasi kebutuhan operator pesawat udara Indonesia Terhadap lulusan SMK yang memiliki kompetensi perawatan.. Sebagaimana terlihat pada Tabel 1, jumlah pengajar kompetensi keahlian perawatan tidak memadai dan tenaga pengajar baru tidak memiliki kompetensi produktif tersebut karena belum punya pengalaman di indiustri penerbangan dan pelatihan.

Tabel 1 Data Tenaga Pengajar SMKN 12 Kota Bandung

(Sumber : Data Tenaga Pengajar SMKN 12 Kota Bandung Tahun Ajaran 2018/2019)

\begin{tabular}{|l|l|l|c|c|c|c|c|c|c|}
\hline \multirow{2}{*}{ No } & \multirow{2}{*}{$\begin{array}{c}\text { Status } \\
\text { pengajar }\end{array}$} & \multirow{2}{*}{ Jumlah } & \multicolumn{2}{|c|}{ Latar Belakang Pendidikan } & \multicolumn{4}{|c|}{ Bidang Ajar } \\
\cline { 4 - 11 } & & $\begin{array}{c}\text { Tek. } \\
\text { Mesin }\end{array}$ & $\begin{array}{c}\text { Non Tek. } \\
\text { Mesin }\end{array}$ & TPU & AP & EA & Mfktr & Lainnya \\
\hline 1 & PNS & 55 org & 21 & 23 & 1 & 10 & 6 & 8 & 31 \\
\hline 2 & Non PNS & 36 org & 5 & 31 & 0 & 1 & 2 & 6 & 27 \\
\hline
\end{tabular}

Keterangan:

TPU: Teknik Pesawat Udara, AP: Airframe Powerplant, EA: Electrical Avionics, Mfktr : Manufaktur (EPU,KRPU,KBPU)

\section{Identifikasi Permasalahan Mitra}

Analisis situasi sebagaimana tersebut diatas memperlihatkan beberapa permasalahan utama yang dihadapi mitra kegiatan :
a. Pengajar baru latar belakang Pendidikan kejuruan umum
b. Kesempatan pelatihan bidang aircraft maintenance
c. Kurang pengalaman magang di industry penerbangan 
d. Fasilitas praktik Airframe dan Powerplant kurang memadai
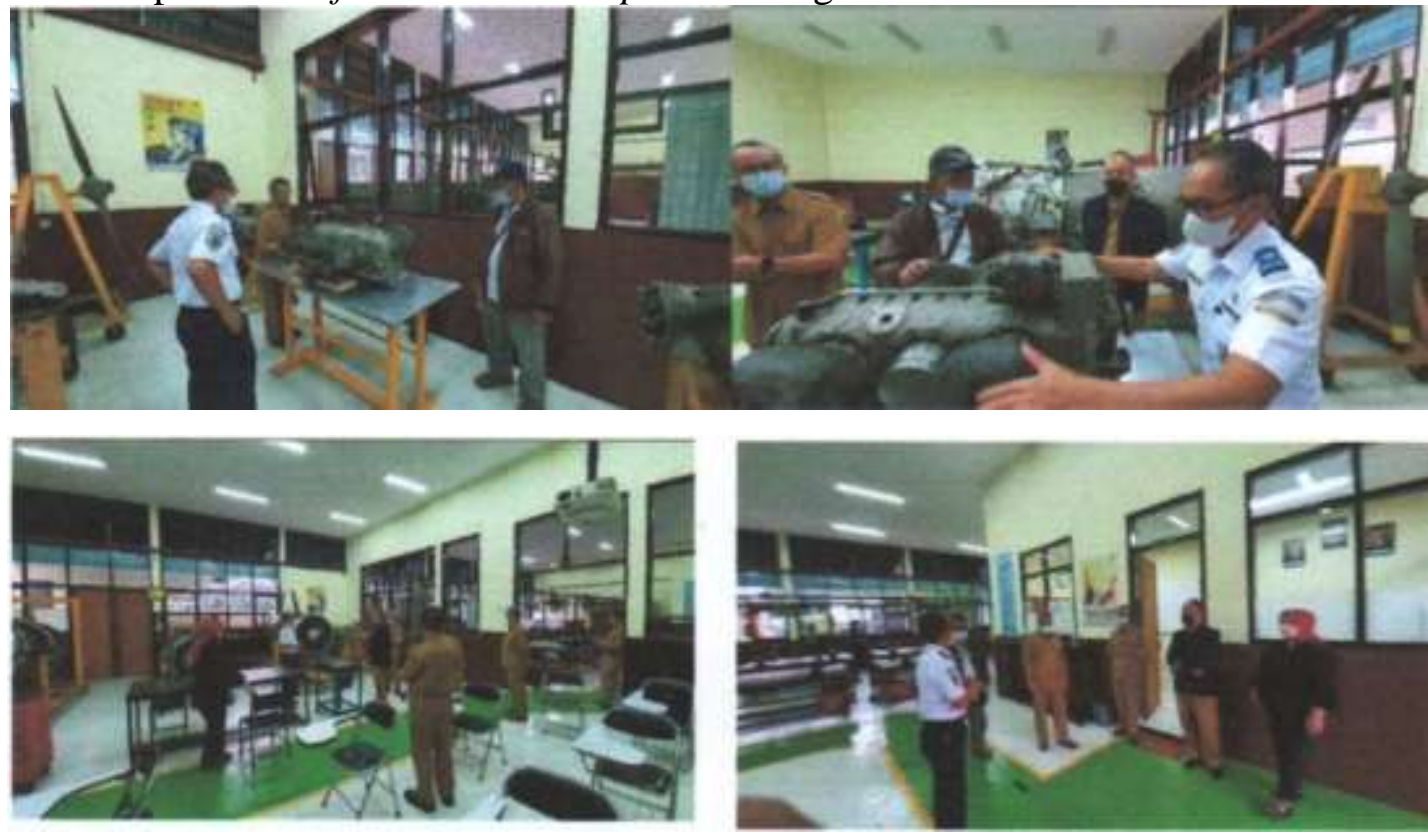

Gambar 2 Asesment Terhadap Fasilitas Praktik di Jurusan Airframe and Powerplant Mitra Kegiatan

\section{Solusi Terhadap Permasalahan Mitra}

Solusi permasalahan mitra pada dasarnya dapat dikerucutkan menjadi:

a. Kesempatan Magang

b. Kesempatan Pelatihan On site

\section{Luaran yang diharapkan}

Luaran utama dari kegiatan Pelatihan on site praktik overhaul mesin piston pesawat ini adalah kemampuan peserta untuk melakukan praktik dasar overhaul sesuai dengan prosedur dan peggunaan perkakas yang tepat dalam manual, terukur dalam luaran Sertifikat telah mengikuti kegiatan pelatihan. Setiap peserta akan mendapatkan kesempatan untuk practical assessment sesuai dengan aspek - aspek penilaian sehingga keterampilan dapat terukur oleh pelatih dan dinyatakan dengan Sertifikat.

\section{Rencana Capaian Luaran}

Untuk mendapatkan luaran utama berupa sertifikat tersebut, peserta harus melalui langkahlangkah dibawah ini:

a. Mengikuti kelas teori secara virtual melalui zoom meeting untuk mendapatkan pemahaman tentang konsep overhaul, technical publication, manual dan penggunaan perkakas special tools yang tepat.

b. Melaksanakan Praktik overhaul mesin piston didampingi pelatih dengan menggunakan perkakas dan manual yang sesuai

c. Melaksanakan practical assessment dengan pelatih sebagai penguji praktik untuk mengukur pencapaian tujuan pelatihan

d. Peserta yang telah mengikuti practical assessment mendapatkan sertifikat.

Berdasarkan uraian permasalahan tersebut, beberapa permasalahan dapat saling memiliki keterkaitan antara satu dan lain. Kurangnya kesempatan magang dan pelatihan serta fasilitas praktik dapat diantisipasi dengan bentuk pelatihan dengan jumlah jam yang proporsional antara 
teori dan praktik praktis, termasuk penggunaan special tools dan engine yang langsung dapat dipraktikkan pada saat pelatihan..

Sejalan dengan kegiatan pengabdian kepada masyarakat pada pelatihan bagi guru SMK Penerbangan di sekitar wilayah Kota Surakarta dan sekitarnya memperoleh updating terkait dengan materi ajar sehingga mendapatkan pemahaman menyeluruh terkait dengan keilmuan yang terus menerus mengalami kemajuan (Sihono et al., 2021). Pelatihan untuk guru SMK Penerbangan yang dilakukan dengan bahan ajar yang aplikatif memberikan pengalaman nyata dalam sesi praktik dalam pelatihan (Viverawati, 2021; Indrawan et al., 2021). Disamping itu peltihann ini juga dapat meningkatkan literasi dari para pegawai khususnya para pengajar (Soleh, Oka, \& Kristiawan, 2020).

Disamping itu, kegiatan ini akan meningkatkan kesadaran para pengajar mengenai keselamatan dalam bidang penerbangan (Fatonah et al., 2020). Tujuan kegiatan dirumuskan berdasarkan lingkup kegiatan pengabdian kepada masyarakat PPI Curug dan analisis kebutuhan calon mitra. Dengan lingkup kegiatan pengabdian kepada masyarakat yang dapat didukung oleh tim adalah bidang pelatihan dan sesuai kebutuhan calon mitra adalah SMK Penerbangan, sehingga tujuan kegiatan adalah memberikan pelatihan bidang perawatan mesin piston pesawat udara kepada pengajar bidang produtif jurusan Airframe dan Powerplant untuk meningkatkan kompetensi pengajar bidang produktif.

\section{Metode}

Metode pelaksanaan kegiatan pengabdian kepada masyarakat ini berbentuk tahapan tindakan yang akan dilakukan dalam kegiatan tersebut, yang terdiri dari:

\section{Perumusan Tim}

Tahapan kegiatan ini merupakan tahapan awal dengan melakukan perumusan tim kegiatan. Tim terdiri dari dosen yang memiliki kualifikasi dan kompetensi pada bidang masing - masing yang menjadi dasar penunjukan anggota tim. Tim terdiri dari satu ketua tim dan empat anggota. Ketua tim bertugas melakukan koodinasi semua tahapan kegiatan dan merangkap pelaksana kegiatan, anggota tim bertugas melakukan kegiatan inti.
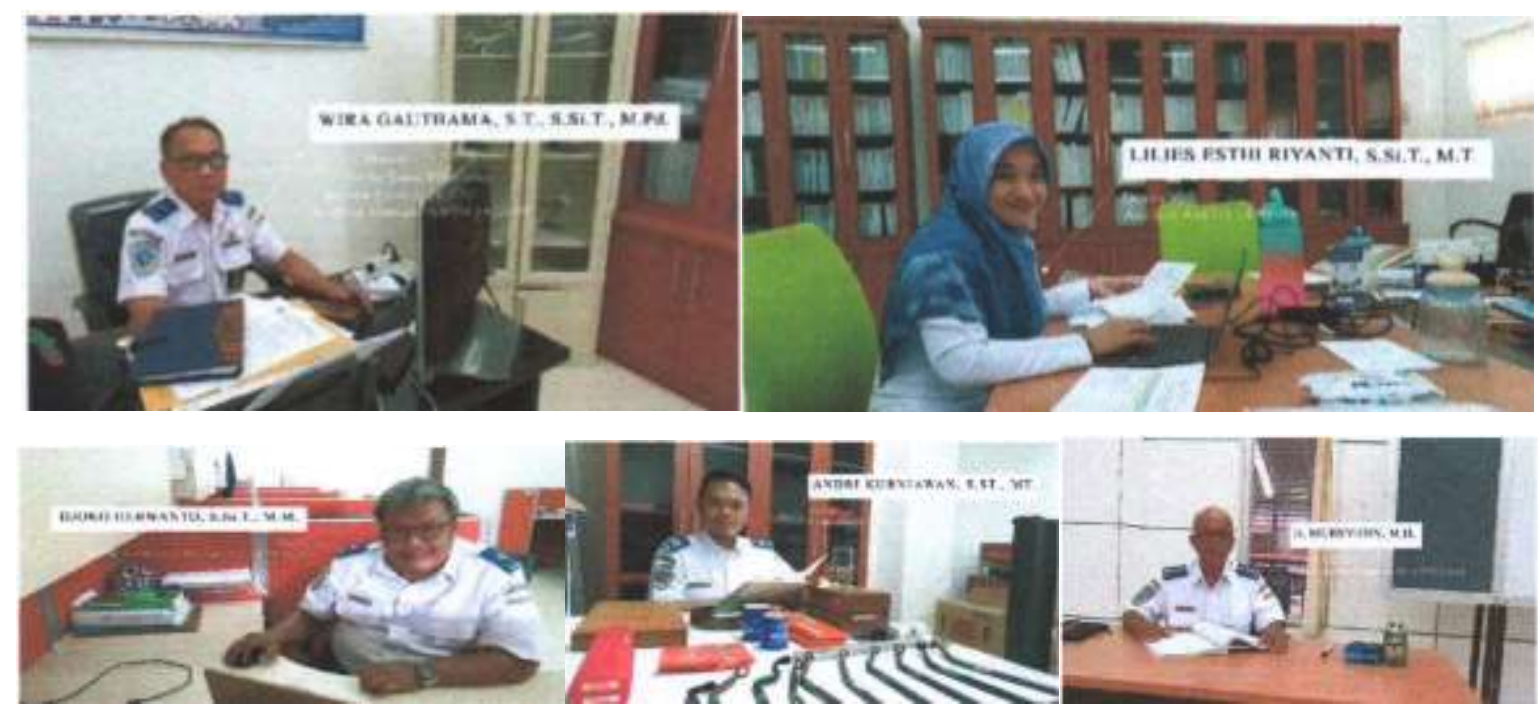

Gambar 3 Susunan Anggota Tim PKM Prodi TPU PPI Curug 


\section{Identifikasi Sasaran Kegiatan}

Tahapan ini dilakukan untuk menentukan sasaran kelompok masyarakat yang akan dijadikan mitra dalam kegiatan pengabdian kepada masyarakat dan bidang kegiatan yang dibutuhkan mitra dan disesuaikan dengan kompetensi tim dan lingkup kegiatan pengabdian kepada masyarakat PPI Curug. Berdasarkan hal tersebut, mitra potensial dalam kegiatan ini adalah tenaga pengajar bidang produktif SMKN 12 Kota Bandung karena memiliki baseline yang sama dengan kompetensi keahlian tim pengabdian masyarakat pada bidang pengajaran teknik pesawat udara.

\section{Analisis Masalah dan Kebutuhan Mitra}

Berdasarkan riset pendahuluan, komunikasi dan data yang tersedia sebagaimana tersebut diatas terlihat bahwa terjadi ketimpangan kompetensi guru - guru produktif pada jurusan Airframe dan Powerplant yang umumnya berlatar belakang sarjana kejuruan umum dan belum memiliki keterampilan yang memadai melaksanakan pembelajaran sesuai dengan tujuan yang diharapkan. Kompetensi tersebut umumnya dapat diperoleh oleh pengajar yang tidak berlatar belakang aircraft maintenance melalui skema magang di indusri penerbangan (Bengkel perawatan pesawat udara ataupun operator pesawat) dan juga melalui skema pelatihan. Berdasarkan data tersebut, bidang kegiatan yang dimungkinkan dilakukan oleh tim pengabdian kepada masyarakat dan yang dibutuhkan oleh mitra adalah kegiatan pelatihan on site.

\section{Menentukan Prioritas Solusi Masalah}

Permasalahan umum mitra adalah kurangnya jumlah dan kompetensi pengajar produktif. Permasalahan utama mitra adalah jumlah dan kompetensi pengajar bidang produktif pada jurusan Airframe dan Powerplant khususnya dalam melakukan praktek overhaul mesin piston masih kurang memadai dikarenakan pada umumnya pengajar belum memiliki latar belakang pengalaman dan pelatihan perawatan mesin piston pesawat terbang dan perkakas untuk melakukan overhaul tidak memadai.

\section{Persiapan}

Tahapan persiapan dilakukan tim melalui koordinasi teknis internal, koordinasi dengan Pusat PPM PPI Curug dan koordinasi dengan mitra kegiatan. Persiapan teknis meliputi jadwal dan materi pelatihan, media, lokasi, peserta, transportasi, akomodasi, dan alat bantu pelatihan lainnya. Seperti
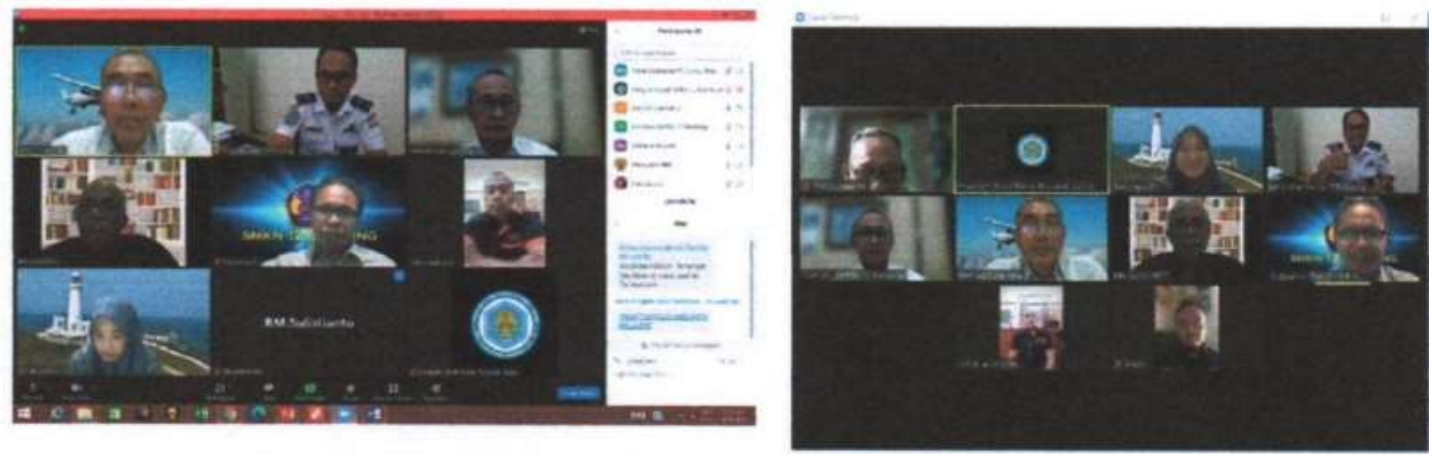

Gambar 4 Rapat Koordinasi Eksternal Secara Virtual dengan Mitra Kegiatan SMKN 12 Pada 14 September 2021 


\section{Hasil dan Pembahasan}

1. Pelaksanaan Kegiatan dan Pendampingan

Pelaksanaan kegiatan utama dilakukan selama 40 jam pelatihan yang terdiri dari :

1) Sesi pembekalan konsep perawatan mesin piston pesawat, Dilaksanakan pada Senin, 11 Oktober 2021 dilaksanakan secara klasikal dalam satu ruang kelas virtual selama 8 jam (1 hari). Materi terdiri dari konsep dasar perawatan dan overhaul mesin piston, cara menginterpretasikan manual dan technical publication lain, serta cara penggunaan perkakas perawatan mesin piston baik secara general tools maupun special tools. 2) Sesi praktik pengenalan dasar overhaul mesin piston, pelatihan materi praktek dilakukan secara tatap muka dengan Prokes selama 24 jam (3 hari) di lokasi mitra kegiatan SMKN 12 Bandung. Dilakukan dengan pengelompokan peserta menjadi 3 kelompok (dua kelompok terdiri dari 7 orang dan satu kelompok terdiri dari 6 orang) dan didampingi oleh satu pelatih pendamping tiap kelompok. Materi terdiri dari top end overhaul, bottom end overhaul, repair, dan measurement dengan menggunakan perkakas, prosedur dan manual yang tepat. 3) Sesi practical assessment, sesi evaluasi praktik dilakukan selama 8 jam (1 hari). Setiap kelompok diberi tugas untuk melakukan top end overhaul atau bottom end overhaul atau measurement of parts dengan benar sesuai dengan prosedur, manual dan penggunaan perkakas yang tepat. Tim pendamping bertugas melakukan penilaian dan feedback kepada peserta untuk perbaikan.

Seluruh kegiatan telah didokumentasikan dalam bentuk video dan telah broadcast secara bertahap melalui website dan medsos PPI C baik Instagram maupun Youtube yang dapat dilihat pada alamat https://youtu.be/SSIGM_HM25c dan beberapa cuplikan kegiatan dibawah ini :

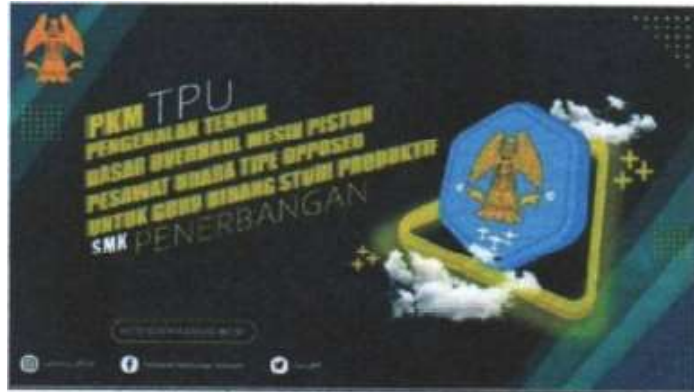

Virtual Background Training Hari Ke 1

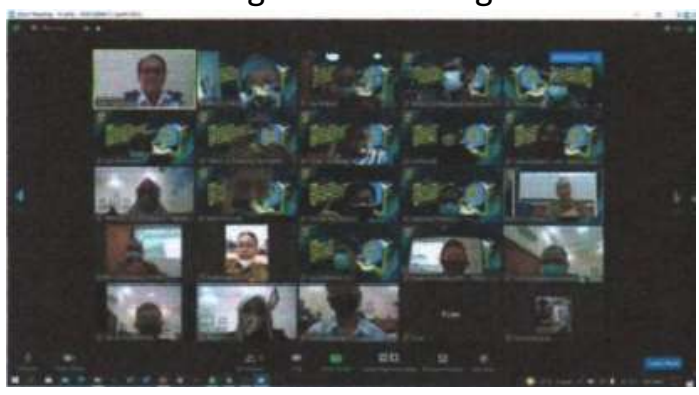

Pembukaan dan Belajar Sesi 1

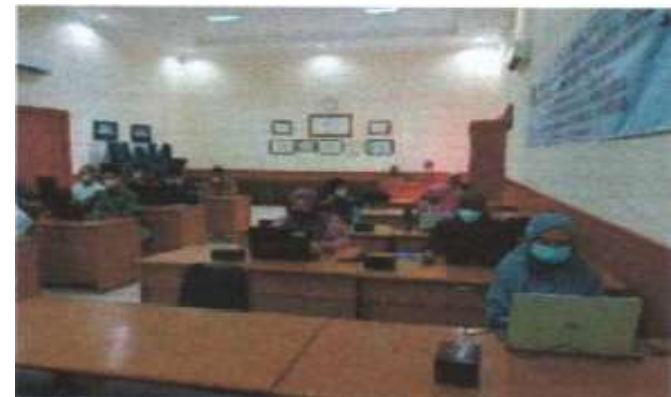

Peserta di Ruang Kelas Online SMKN 12

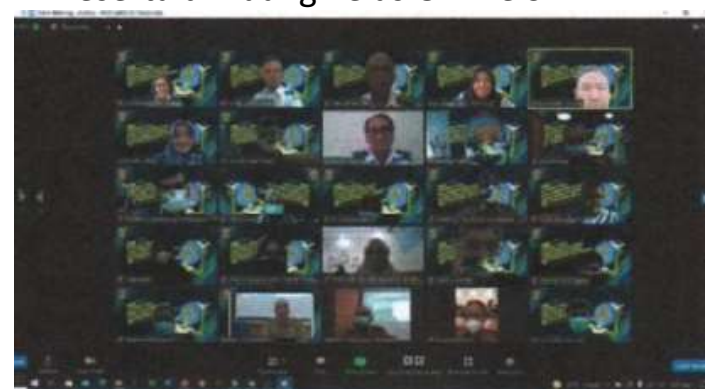

Belajar Sesi 2 


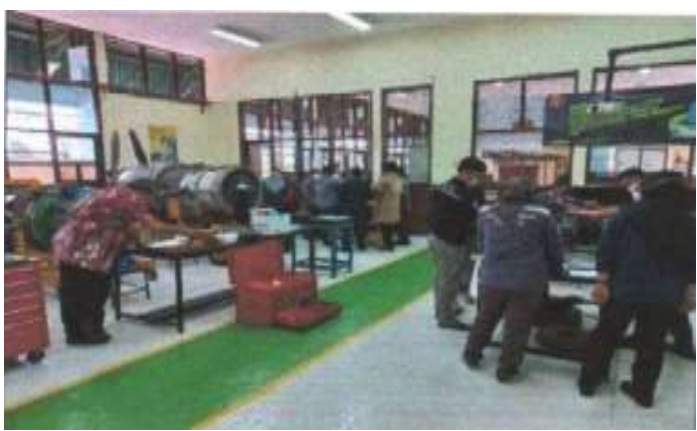

Suasana Saat Assessment Praktek

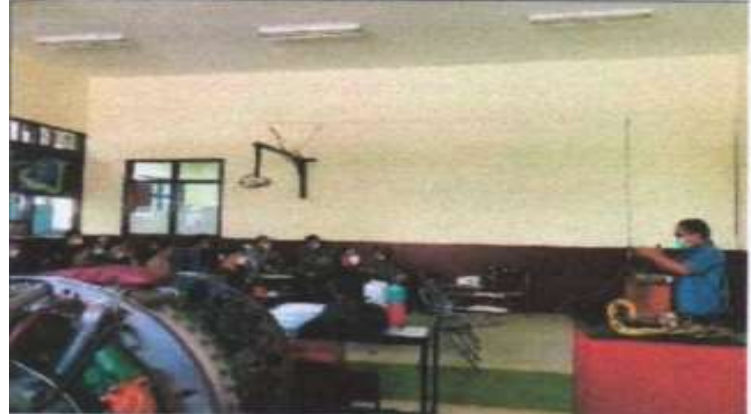

Pre Briefing sebelum Praktek

Gambar 5 Beberapa Rekaman Kegiatan dari Hari Ke-1 hingga Ke-4

2. Evaluasi kegiatan

Evaluasi dilakukan untuk mengukur pencapaian tujuan kegiatan pengabdian kepada masyarakat dalam bentuk pelatihan on site ini sehingga dari hasil evaluasi tersebut dapat dikembangkan perbaikan - perbaikan yang diperlukan pada kegiatan berikutnya. Dari 20 responden peserta, 19 responden telah mengirimkan jawaban terhadap pertanyaan - pertanyaan dalam kuesioner. Berdasarkan data tersebut terlihat bahwa pandangan peserta terhadap kapabilitas tim pengajar dan mater sangat positif, tergambar rata - rata 95\% menyatakan sangat setuju dan setuju tentang baiknya kapabilitas pengajar, kejelasan dan sistematika materi, implementasi konsep dengan praktek, selalu terdapat kesempatan peserta untuk menyampaikan ide, baiknya kejelasan jawaban dan kejelasan bahasa dalam penyampaian materi. Hasil kegiatan ini selaras dengan hasil kegiatan pengabdian yang dilakukan Sihono et al., (2021) minat balikan yang positif dari sasaran kegiatan yang merupakan guru-guru SMK penerbangan, setelah mengikuti pelatihan yang lebih banyak dalam bentuk praktek. Sehingga para peserta diharapkan akan mendapatkan kompetensi sesuai dengan bidangnya (Soleh et al., 2019).

Selain itu, survey kepuasan peserta terhadap kegiatan juga memperlihatkan hal positif. Hal ini tergambar rata - rata 95\% peserta menyatakan kepuasannya (sangat setuju dan setuju) terhadap materi yang telah sesuai harapan, kebutuhan, dapat diimplementasikan dan mampu meningkatkan kemampuan dan keterampilan peserta, puasnya terhadap layanan dan profesionalitas dari tim PKM PPI Curug, baiknya sumber daya pendukung kegiatan, dan peserta menyatakan sangat bersedia mengikuti kegiatan sejenis dengan materi yang berbeda. Kepuasan dalam layanan pendidikan vokasi menjadi indikator kegiatan pembelajaran yang dilakukan bernilai dampak (Yusuf, \& Mukhadis, 2018). Secara umum peserta menyatakan kepuasannya terhadap kegiatan pengabdian masyarakat ini.

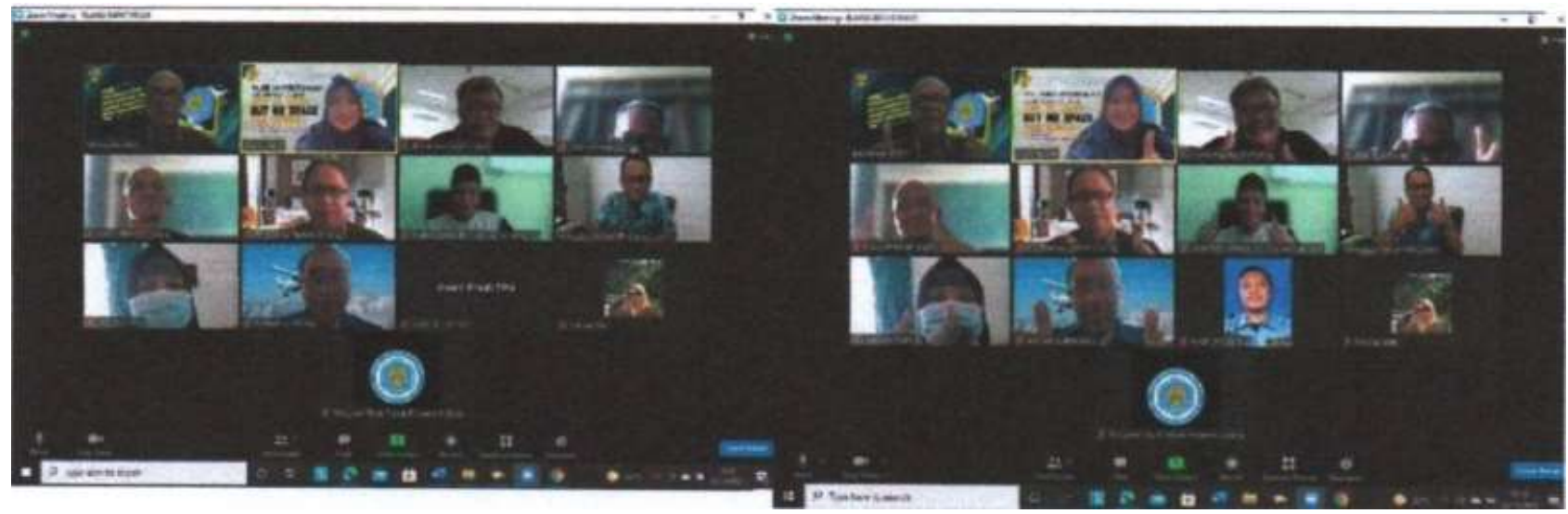

Gambar 6 Rapat Evaluasi Kegiatan PKM

Darmabakti: Jurnal Inovasi Pengabdian dalam Penerbangan 


\section{Kesimpulan}

Pelaksanaan kegiatan pengabdian kepada masyarakat dari Dosen Teknik Pesawat Udara Politeknik Penerbangan Indonesia Curug Tangerang dengan mitra kegiatan SMKN 12 Bandung dengan tema Pengenalan Teknik Dasar Overhaul Mesin Piston Pesawat Udara Tipe Opposed Untuk Guru SMK Penerbangan ini berhasil dengan baik dan bermanfaat bagi mitra kegiatan. Dan kegiatan dapat dilanjutkan dengan beberapa kegiatan penelitian dan pengabdian kepada masyarakat berikutnya.

\section{Ucapan terima kasih}

Ucapan terimakasih disampaikan kepada Mitra Kegiatan SMKN 12 Bandung yang telah memberikan ijin sehingga dapat terlaksananya kegiatan pengabdian kepada masyarakat. Adapun juga tersampaikan kepada semua Bapak/Ibu Guru dan Murid-Murid pada SMKN 12 Bandung yang telah bersedia bekerja sama dalam kegiatan pengabdian kepada masyarakan Politeknik Penerbangan Indonesia Curug Tangerang.

\section{Daftar Pustaka}

Crane, D. (1996). aviation maintenance technician seriea: powerplant (T. MICHMERHEUZEN (ed.)). AVIATION SUPPLIES \& ACADEMY.

Fatonah, F., Wildan, M., Purnomo, S., \& Soleh, A. M. (2020). Design Of High Gain Low Noise Amplifier At Base Station Receiver VOR Equipment For Ground Check Monitoring As Learning Media In Civil Aviation Academy. International Journal of Progressive Sciencies and Technologies, 397-402.

Indrawan, S. ., Nugraha, N. B. ., Saputra, J. ., \& Sirlyana, S. (2021). In House Training (IHT) Pembelajaran di Masa Pandemi dengan Blended Learning SMK N 5 Dumai. Jubaedah : Jurnal Pengabdian dan Edukasi Sekolah (Indonesian Journal of Community Services and School Education), 1(3), 240-246. https://doi.org/10.46306/jub.v1i3.45.

John M. Gross. (2002). Fundamental of Preventive Maintenance. American Management Association.

Kinnison Harry A. (2004). Aviation Maintenance Management. McGRaw-Hill.

Michael J. Kroes, watkins, W. A. D. F. (1993). Aircraft Maintenance and Repair (Sixth). Macmillan/McGraw-Hill.

Murjito, G. (n.d.). Metoda Pengabdian Kepada Masyarakat (Diakses Ta). https://www.slideshare.net/FitriRiyanto/metoda-pengabdian-pada-masyarakat-pak-gatot1.

Pusat Penelitian dan Pengabdian kepada Masyarakat PPI Curug. (2020). Panduan Penelitian dan Pengabdian Kepada Masyarakat. PPI Curug.

RI, D. K. U. dan P. P. U. K. P. (1998). Advisory Circular No. 65-2.

Sihono, Fatkulloh, A., Saputro, R., Herwanto, D., Kalbuana, N., \& Kurnianto, B. (2021). Pemantapan dan Refreshing Materi Electrical \& Electronik untuk Guru SMK Penerbangan di Jawa Tengah dan Sekitarnya. Jubaedah: Jurnal Pengabdian dan Edukasi Sekolah (Indonesian Journal of Community Services and School Education), 1(1), 12-19. https://doi.org/10.46306/jub.v1i1.2.

SMKN 12 Kota Bandung. (2020). Data Keadaan Tenaga Pendidik Tahun Ajaran 2018/2019.

Soleh, A. M. (2019). Pengembangan Media Simulator pada Pendidkan dan Pelatihan Foam Tender Operation and Defensive Driving di Balai Pendidikan dan Pelatihan Penerbangan Palembang. rosiding Seminar Nasional Program Pascasarjana Universitas PGRI Palembang, 108-119.

Soleh, A. M., Tobari, \& Kesumawati, N. (2019). Development Of The Practical Manual As A Learning Media For SimulatorAircraft Rescue And Fire Fighting. INTERNATIONAL JOURNAL OF SCIENTIFIC \& TECHNOLOGY RESEARCH, 523-526. 
Soleh, A. M., Oka, I. G. A. M., Kristiawan, M. (2020). Kondisi Literasi Media Digital dalam Aktifitas Kerja Pegawai Politeknik Penerbangan Palembang. Ilmu Pendidikan: Jurnal Kajian Teori dan Praktik Kependidikan, 5(2), 51-62. http:// dx.doi.org/10.17977/um027v5i22020p051

U.S. Department of Transportation. (n.d.). Aviation Mechanic Airframe Practical Test Standard, FAA-S8081-27 w/ Changes 1,2, \& 3 (20591st ed.). FAA Flight Standard Service.

US Department of Transportation. (2003). Aviation Mechanic Powerplant Practical Test Standard, FAA-S-80881-28 w/ Changes 1 \& 2. FAA Flight Standard Service.

Vincent II, J. . (n.d.). “Community development practice” in Rhonda, P dan Pitman, R.H (ed). An Introduction to Community Development, (p. Hal. 58-74). https://figshare.com/articles/Metode_Pelaksanaan_Pengabdian_kepada_Masyarakat/7011266/

Viverawati. (2021). Best Practice Mengajarkan Materi Diklat Dengan Menggunakan Modul Penghitungan Ticket Penerbangan Internasional di Masa Pandemi bagi Guru SMK-UPW. VOCATIONAL : Jurnal Inovasi Pendidikan Kejuruan, 1 (3), 63-71.

Yusuf, A. R., \& Mukhadis, A. (2018). Model Pengembangan Profesionalitas Guru sesuai Tuntutan Revitalisasi Pendidikan Vokasi Indonesia. Lectura: Jurnal Pendidikan. https://doi.org/10.31849/lectura.v9i2.1613 